\title{
PENGARUH MINDFULNESS TERHADAP CAREGIVER BURDEN LANSIA DENGAN DEMENSIA DI PANTI WREDA
}

\author{
Heru Ginanjar Triyono ${ }^{1}$ Meidiana Dwidiyanti ${ }^{2}$, Rita Hadi Widyastuti ${ }^{3}$ \\ ${ }^{2,3}$ Departement of Nursing, Faculty of Medicine, Diponegoro University, Indonesia \\ ${ }^{1}$ Student of Master Program in Nursing, Faculty of Medicine, Diponegoro University, Indonesia \\ E-Mail: mdwidiyanti@gmail.com
}

\begin{abstract}
Data yang diperoleh pada bulan November 2017 pada saat dilakukan screening didapatkan data bahwa terdapat 35 Caregiver mengalami burden dengan kategori ringan sampai berat, yang terdiri dari 10 orang mempunyai burden ringan, 23 orang burden sedang dan 1 orang mempunyai burden berat. Kemudian pada saat dilakukan wawancara menyatakan bahwa caregiver merasa kelelahan karena kurang lebih 8 jam merawat lansia dengan demensia, Caregiver juga sering menahan emosi terkait dengan tingkah laku lansia yang sulit diatur. Metode penelitian yang digunakan dalam penelitian ini adalah "quasy experimental pre-post test with control group, jumlah sampel 34 orang yang diambil dengan purposive sampling, intervensi yang diberikan melalui intervensi mindfulness.

Pada kelas intervensi, terdapat perbedaan tingkat caregiver burden secara signifikan antara pre-test dan post-test $(p$-value $=0,000<\alpha=0,05)$. Dari hasil tersebut maka pemberian perlakuan berpengaruh signifikan dalam menurunkan tingkat Caregiver Burden. Dilihat secara deskriptif, rata-rata tingkat caregiver Burden pada kedua kelas kontrol baik pre-test maupun post-test berada pada level sedang. Intervensi mindfulness dapat membantu permasalahan caregiver yang merawat lansia dengan demensia, emosional dari caregiver, khususnya burden, ekonomi, burden sosial, burden psikologis. Mindfulness lebih efektif ketika caregiver aktif melakukan latihan secara kontinu sehingga tingkat caregiver burden dapat berkurang
\end{abstract}

Keyword: Caregiver burden, elderly dementia, Nursing home, mindfulness

\section{LATAR BELAKANG}

Meningkatnya jumlah demensia berdampak pada perubahan perilaku lansia. Dampak yang terjadi pada lansia dengan demensia adalah munculnya beberapa gangguan yang terjadi, antara lain, pemenuhan aktivitas hidup sehari-hari secara mandiri, dan munculnya ketidakstabilan emosi (Maestre et al., 2018).

Ketidakmampuan lansia demensia menurut International Classification of Diseases 10 pada tingkat paling awal dari lansia memiliki kehilangan ingatan yang berdampak pada terbatasnya pemenuhan kebutuhan dasar secara mandiri, di samping lansia yang memiliki demensia pada tingkat yang lebih berat akan mengalami gangguan dalam menyimpan informasi karena itu orang tua yang mengalami demensia membutuhkan seseorang yang dapat membantu kebutuhan mereka seperti Caregiver (WHO, 2010).

Caregiver yang merawat lansia dengan demensia akan mengalami beberapa masalah termasuk masalah psikososial yang dialami oleh perawat lansia, munculnya keterbatasan dalam berhubungan dengan orang lain, keterbatasan aktivitas sosial dan berkurangnya waktu luang (Sinha, 2018).

Intervensi non-farmakologis yang digunakan dalam beban Caregiver adalah terapi komplementer, terapi komplementer meliputi; Praktek berbasis biologi, pikiran dan tubuh Teknik: Meditasi, praktik latihan berbasis tubuh: pijat atau refleksi, energi Terapi: terapi medan magnet, sistem medis kuno: obat tradisional, ayurveda (Toussaint, 2016). Intervensi Midfulness dianggap memiliki keuntungan empiris dimana terapi Mindfulness 
dapat meningkatkan pengaruh positif dan dapat menurunkan pada Pengasuh. Mindfulness Based Stress Reduction yang dilakukan dalam 8 minggu dapat mengurangi stres dan meningkatkan kesehatan mental (Kaviani, 2011). Upaya telah dilakukan oleh panti jompo untuk mengurangi beban Caregiver, antara lain dengan berputar secara rutin setiap sebulan sekali. Mengingat ini penelitian ini bertujuan untuk Menganalisis efek terapi Mindfulness pada beban Caregiver dalam merawat lansia dengan demensia di Nursing Home pada kelompok intervensi dan kelompok kontrol.

\section{METODE}

Ini adalah penelitian kuantitatif Quasy Experiment pre dan post test di panti jompo harapan asri semarang Jawa Tengah. Kota ini dua kali paling padat penduduknya di negara ini, dengan satu juta tujuh ratus ribu penduduk dan sekitar 150 lansia berusia 60 atau lebih tua yang menerima perawatan di panti jompo (BPS, 2017). Peran pengasuh sangat penting dalam perawatan seperti ini

Penelitian ini diatur dalam persetujuan penuh dengan Deklarasi Asosiasi Medis Dunia Helsinki dan komite Etika Penelitian. Anonimitas peserta dan kerahasiaan informasi dijamin.

2.1 Instrumen

Data dikumpulkan secara individual menggunakan

1. Quesioner terdiri dari informasi sosiodemografi (umur, nama, jenis kelamin, perkawinan, pendidikan status dan penghasilan)

2. Prosedur operasional standar dari Kabat zinn sebagai terapi panduan dengan beban pengasuh

3. Instrumen pengasuh beban zarit untuk mengukur tingkat beban merawat lansia dengan demensia

\section{ANALISIS}

Metode penelitian ini menggunakan mentode penelitian kuantitatif "Quasi Experimental Pre and post test" dengan jumlah sampel 34. Cara pengumpulan data yang digunakan dalam penelitian ini menggunakan kuesioner Zarit Burden Inventory(ZBI) untuk mendapatkan tingkat caregiver burden.

\section{Hasil Penelitian}

\section{Karakteritik Responden}

Tabel 1

Karakteristik Responden penelitian di Panti Wreda

Variabel

Jenis Kelamin

Laki-laki

Perempuan p-value

Usia

20-35 tahun $\quad 12$

36-50 tahun 12

Status Jumlah

$\left(X^{2}\right)$

\section{Perkawinan}

Belum Kawin

Kawin

10

24

120,130

Pendidikan

Terakhir

SMP

SMA

Lama Bekerja

1-5 tahun

6-10 tahun

0,793

\section{2}

0,601

18

0,119

16

Dari tabel 1 sebagian besar responden berjenis kelamin perempuan.Usia caregiver sebagian besar berusia 36-50 tahun yang berjumlah 12 orang, dengan pendidikan terakhir SMA dengan jumlah 24. Rata -rata lama bekerja sebagai caregiver lansia antara 1 sampai dengan 5 tahun berjumlah 18 orang.

\section{Tingkat Caregiver burden sebelum dan sesudah diberikan perlakuan}




\section{Tabel 2}

Tingkat Caregiver burden sebelum dan sesudah diberikan Perlakuan

$\begin{array}{lccccc}\begin{array}{l}\text { Tingkat } \\ \text { Burden }\end{array} & & & & \\ & \begin{array}{l}\text { Pre } \\ \text { test }\end{array} & \text { Postest } & & \\ & 1 & \% & \text { n } & \% \\ \text { Tidak Burden } & & & 2 & 76, \\ & 3 & 8,82 & 6 & 47 \\ \text { Burder Ringan } & 2 & & & 23, \\ & 6 & 76,47 & 8 & 53 \\ \text { Burden Sedang } & 5 & 14,71 & 0 & 0 \\ \text { Burden Berat } & 0 & 0 & 0 & 0\end{array}$

Dari tabel 2 diatas dapat dilihat bahwa mayoritas atau sebagian besar tingkat caregiver burden berada pada level tingkat ringan. Responden caregiver yang tidak mengalami burden pada pengukuran pre-test adalah 3 orang $(8,82 \%)$. sedangkan pada pengukuran post-test sebanyak 26 orang $(76,47 \%)$, Tingkat caregiver burden ringan pada pengukuran pre-test berjumlah 26 orang $(76,47 \%)$, Caregiver burden ringan pada pengukuran post test berjumlah 8 orang $(23,53 \%)$.

\section{Perbedaan Tingkat Caregiver yang merawat lansia dengan demensia sebelum dan sesudah perlakuan}

Tabel 3

Perbedaan Tingkat Caregiver burden yang merawat lansia dengan demensia sebelum dan sesudah diberikan Perlakuan

\section{PEMBAHASAN}

Tingkat pengasuhan yang membebani setelah perawatan pada kelompok intervensi dibagi menjadi responden yang tidak mengalami beban pengasuh sebanyak 26 orang $(76,47 \%)$, caregiver beban beban 8 orang $(23,53 \%)$. Tingkat pengasuhan membebani seseorang yang merawat lansia dengan demensia dipengaruhi oleh beberapa hal, antara lain dipengaruhi oleh jenis kelamin (Kvillemo \& Bränström, 2011). Seks perempuan lebih rentan terhadap stres saat merawat lansia dibandingkan dengan pria. perempuan lebih cenderung stres, sambil merawat lansia dengan demensia dan penyakit kronis (Lolong, 2016). seks perempuan dianggap lebih mampu melakukan perawatan lansia mereka lebih fleksibel dalam merawat sehingga mereka mampu memberikan kenyamanan kepada seseorang yang mereka Peduli (Sinha, 2013).

Kemampuan seseorang untuk beradaptasi dengan stres juga berdasarkan tingkat pendidikan seseorang. Semakin tinggi tingkat pendidikan seseorang akan lebih mampu berpikir rasional dan mampu mempertahankan diri dan beradaptasi dengan stres (Gell, 2015). Beban pengasuh merupakan respons multidimensi terhadap stres fisik, psikologis, sosial, dan keuangan yang terkait dengan pengalaman pengasuh dalam mengasuh (Riasmini, 2015). beban pengasuh yang merawat lansia dengan penyakit kronis secara terperinci, antara lain, gangguan dalam rutinitas sehari-hari, gangguan dalam manajemen perilaku, permintaan waktu dan energi yang tidak sesuai dengan kebutuhan, dan ketidakmampuan pengasuh untuk merawat lansia dengan demensia yang memuaskan (Germain, 2017)

Menunjukkan juga diamati pada tabel

Variabel Mean SD Mean $p$ -

Difference value

$\begin{array}{lllll}\text { - Pretest } \quad 32,00 & 8,20 & 15,47 & 0,00\end{array}$

- Posttest 16,53 5,44

2 dimana analisis mean pretest pada 
kelompok kontrol 45,68 dan Standar Deviasi13,50, posttest 45,85 dan standar deviasi 13,00. Latihan kelompok mindfulness control tidak memiliki pengaruh yang besar terhadap penurunan beban pengasuh yang menyebabkan latihan mindfulness akan berpengaruh jika secara rutin dilakukan selama 6 bulan dengan durasi 10 hingga 35 menit sesuai dengan (Myint, 2011)

Perhatian penuh efektif untuk menghilangkan stres pada pasien dan penyedia layanan kesehatan (pengasuh). Perhatian penuh adalah intervensi yang relatif aman dan dapat dilakukan pada berbagai pasien (Praissman, 2008). Keadaan kesadaran memungkinkan seseorang untuk menjangkau suara "sadar" penuh tidak secara otomatis ke sumber yang diperlukan (Kim, 2017). keterampilan merawat lansia adalah faktor yang paling penting dalam mempengaruhi beban pengasuh. Selain itu perhatian pengasuh lain juga mempengaruhi suasana kenyamanan sehingga dapat mengurangi beban pengasuh dalam merawat lansia di panti jompo (Song \& Lindquist, 2015).

Menunjukkan tabel 2 pengaruh mindfulness pada caregiver burden lansia dengan demenstia di panti jompo dapat dilihat bahwa rata-rata responden rata-rata adalah 16,53 dengan nilai $\mathrm{p} 0,00(\mathrm{p}<0,05)$. Ini berarti intervensi mindfulness yang signifikan untuk mengurangi pengasuh untuk perawatan lansia dengan demensia di panti jompo. Penerimaan perhatian penuh secara signifikan lebih tinggi dibandingkan dengan orang dewasa muda dengan nilai $\mathrm{p}$ $<0,05$. Kesadaran dapat membantu pengasuh merefleksikan semua bentuk pengalaman positif dan negatif yang telah dilalui sehingga dapat menumbuhkan rasa percaya diri pada pengasuh untuk perawatan yang lebih baik bagi lansia (Sundquist, 2017). Keyakinan akan kepercayaan mengarah ke ketulusan saat merawat dan menerima kondisi yang terjadi pada saat ini.

Akhirnya harus dicatat bahwa karena dalam penelitian ini adalah eksperimen Quasy pre dan post test dengan kelompok kontrol untuk mengidentifikasi efek mindfulness dengan penurunan beban pengasuh dalam merawat lansia demensia di panti jompo. Batasan lain dari penelitian ini adalah analisis penurunan beban pengasuh di panti jompo, hasilnya dapat mengembangkan latihan alternatif atau pendamping seperti perhatian sebagai upaya untuk mencegah pengasuhan, yaitu perawatan anak dapat membantu psikologis, fisik dan ekonomi.

\section{KESIMPULAN}

Manajemen stres, dan analisis yang menggunakan metode holistik yang mencakup fisik, psikologis, psiko-agama dan psikososial, terapi kognitif kesadaran dapat mengurangi gejala, stres, kecemasan dan depresi.

Hasil penelitian di panti jompo di Semarang menunjukkan bahwa hasil uji Wilcoxon menunjukkan bahwa ada perbedaan yang lebih signifikan antara sebelum dan sesudah perlakuan dibandingkan dengan kelompok kontrol. Ini karena kelompok intervensi mendapat terapi mindfulness, intervensi mindfulness adalah terapi yang dibuat secara sadar melihat pengalaman individu secara sadar tanpa perlawanan, penilaian atau bereaksi terhadap peristiwa yang sedang dialami (Crane et al., 2017)

\section{Referensi}

BPS. (2017). Kota Semarang Dalam Angka Semarang Municipality in Figure.

Crane, R. S., Brewer, J., Feldman, C., KabatZinn, J., Santorelli, S., Williams, J. M. G., \& Kuyken, W. (2017). What Defines Mindfulness-Based Programs? the warp 
and the weft. Psychological Medicine, 47(6), 990-999. https://doi.org/10.1017/S00332917160033 17

Gell. (2015). Patterns of Technology Use Among Older Adults With and Without Disabilities. Gerontologist, 55(3), 412421. https://doi.org/10.1093/geront/gnt166

Germain. (2017). Management of Elderly Patients Suffering from Cancer: Assessment of Perceived Burden and Of Quality of Life of Primary Caregivers. Journal of Geriatric Oncology, 8(3), 220 228.

https://doi.org/10.1016/j.jgo.2016.12.001

Kaviani. (2011). Mindfulness-Based Cognitive Therapy (MBCT) Reduces Depression and Anxiety Induced by Real Stressfull Setting in Non-Clinical Population. International Journal of Psychology and Psychological Therapy, 11(2), 285-296.

Kim. (2017). Burden on Family Caregivers of the Elderly In Oncologic Palliative Care. European Geriatric Medecine, 1-5. https://doi.org/10.1016/j.eurger.2017.06.0 01

Kvillemo, P., \& Bränström, R. (2011). Experiences of a Mindfulness-Based Stress-Reduction Intervention Among Patients With Cancer. Cancer Nursing, 34(1), 24-31. https://doi.org/10.1097/NCC.0b013e3181e 2d0df

Lemeshow. (1990). Part 1: Statistical Methods for Sample Size Determination. Adequacy of Sample Size in Health Studies, 247. https://doi.org/10.1186/1472-6963-14-335

Lolong. (2016). Hubungan Kejadian Stress Penyakit Hipertensi pada Lansia Di Balai Penyantunan LansiaKota, 4, 1-5.

Maestre, G. E., Mena, L. J., Melgarejo, J. D., Aguirre-Acevedo, D. C., Pino-Ramírez, G., Urribarrí, M., ... Scarmeas, N. (2018). Incidence of Dementia in Elderly Latin Americans: Results of the Maracaibo Aging Study. Alzheimer's and Dementia, 14(2), 140-147. https://doi.org/10.1016/j.jalz.2017.06.263 6

Myint, K. (2011). The Effect of Short-Term Practice of Mindfulness Meditation in Alleviating Stress in University Students. Biomedical Research, 22(2), 165-171.
Praissman, S. (2008). Mindfulness-Based Stress Reduction: A literature review and Clinician's Guide. Journal of the American Academy of Nurse Practitioners, 20(4), 212-216. https://doi.org/10.1111/j.17457599.2008.00306.x

Riasmini. (2015). Prediktor Pola Caregiving Keluarga Terhadap Lanjut Usia. Jurnal Keperawatan, 1(1), 57-66.

Sinha. (2013). The Impact of Caring on Family Carers. Statistics Canada, (89), 1-21. https://doi.org/10.1162/ISEC

Sinha. (2018). Caregiver Burden in Alzheimertype Dementia and Psychosis: A Comparative Study from India. Asian Journal of Psychiatry. https://doi.org/10.1016/j.ajp.2017.01.002

Song, Y., \& Lindquist, R. (2015). Effects of Mindfulness-Based Stress Reduction on Depression, Anxiety, Stress and Mindfulness in Korean Nursing Students. Nurse Education Today, 35(1), 86-90. https://doi.org/10.1016/j.nedt.2014.06.010

Sundquist. (2017). The Effect of Mindfulness Group Therapy On a Broad Range of Psychiatric Symptoms: A Randomised Controlled Trial in Primary Health Care. European Psychiatry, 43, 19-27. https://doi.org/10.1016/j.eurpsy.2017.01.3 28

Toussaint, L. (2016). Effects of Lifetime Stress Exposure on Mental and Physical Health in Young Adulthood: How Stress Degrades and Forgiveness Protects Health, 344(6188), 1173-1178. https://doi.org/10.1126/science.1249098.S leep

WHO. (2010). International Statistical Clasification of Desease and Related Health Problem 10 Revision, 2. Retrieved from http://www.who.int/classifications/icd/IC D10Volume2_en_2010.pdf 